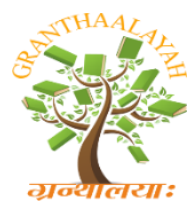

\author{
INTERNATIONAL JOURNAL OF RI
GRANTHAALAYAH \\ A knowledge Repository
}

Social

\title{
THE SEQUENTIAL EVPLANATORY ANALYSIS OF WORK QUALITY BASED ON PRINCIPAL SUPERVISION, WORK DISCIPLINE, AND PEDAGOGICAL COMPETENCE (STUDIY AT JUNIOR HIGH SCHOOL TEACHERS IN THE CITY JAMBI)
}

\author{
Sumirah ${ }^{* 1}$ \\ ${ }^{* 1}$ Lecturer in Posgraduate State Islamic University Sulthan Thaha Syaifuddin \\ Jambi - Indonesia
}

\begin{abstract}
The objectives of this research is to examine the correlation between independent variables such as: principal supervision, work discipline, and pedagogical competence with an dependent variable, Work Quality. The research was conducted on 284 Teacher's Junior high school who were selected by propotional random sampling in Jambi City; meanwhile the hypothesis test was conducted on 0.05 significance level.

This research was conducted by using sequential explanatory mixed methods that prioritize research with quantitative methods and followed by qualitative methods to obtain the results of a significant and comprehensive.

The quantitative research concludes that: (1) there is a positive and significant correlation $(\mathrm{r}=$ $0.4621, \mathrm{p}<0.01$ ) between principal supervision with the work quality, coefficient of determination $0.2127(\mathrm{r} 2=21.27 \%)$ with the regression equation $\mathrm{Y}=83.539+0,450 \mathrm{X} 1,(2)$ there is a positive and significant correlation $(\mathrm{r}=0.4834, \mathrm{p}<0.01)$ between work discipline with the work quality, coefficient of determination $0.2337(\mathrm{r} 2=23.37 \%)$ with the regression equation $\mathrm{Y}=91.901+$ $0,427 \mathrm{X} 2$, (3) there is a positive and significant correlation $(\mathrm{r}=0.5082, \mathrm{p}<0.01)$, coefficient of determination $0.2583(\mathrm{r} 2=25.83 \%)$ between pedagogical competence with the work quality with the regression equation $\mathrm{Y}=91.901+0,427 \mathrm{X} 3$, (4) there is a positive and significant correlation $(\mathrm{r}$ $=0.5815, \mathrm{p}<0.01)$ between principal supervision and discipline of work together with the work quality, coefficient determination $0.3381(\mathrm{r} 2=33.81 \%)$ with a regression equation $\mathrm{y}=43.63+$ $0,403 \mathrm{X} 1+0,388 \mathrm{X} 2,(5)$ there is a positive and significant correlation $(\mathrm{r}=0.5762, \mathrm{p}<0.01)$ between principal supervision and pedagogical competence together with the work quality, coefficient of determination $0.3320(\mathrm{r} 2=33.20 \%)$ with a regression equation $\mathrm{y}=48.18+0,333 \mathrm{X} 1+1,646 \mathrm{X} 3$, (6) there is a positive and significant relationship $(r=0.6188, p<0.01)$ between discipline of work and pedagogical competence together with the work quality, coefficient of determination 0.3829 $(\mathrm{r} 2=38.29 \%)$ with a regression equation $\mathrm{y}=32.95+0.413 \mathrm{X} 2+1,953 \mathrm{X} 3$, (7) there is a positive and significant correlation $(\mathrm{r}=0.7171, \mathrm{p}<0.01)$ between principal supervision, discipline of work and pedagogical competence with the work quality, determination coefficient $0.5143(\mathrm{r} 2=$ $51.43 \%$ ) with a regression equation $\mathrm{Y}=7.373+0,286 \mathrm{X} 1+0,388 \mathrm{X} 2+1,643 \mathrm{X} 3$.
\end{abstract}


Keywords: Principal Supervision; Work Discipline; Pedagogical Competence; and the Work Quality.

Cite This Article: Sumirah. (2019). "THE SEQUENTIAL EVPLANATORY ANALYSIS OF WORK QUALITY BASED ON PRINCIPAL SUPERVISION, WORK DISCIPLINE, AND PEDAGOGICAL COMPETENCE (STUDY AT JUNIOR HIGH SCHOOL TEACHERS IN THE CITY JAMBI)." International Journal of Research - Granthaalayah, 7(12), 337-348. https://doi.org/10.29121/granthaalayah.v7.i12.2019.328.

\section{Introduction}

\section{Background}

The importance of the quality of teacher work towards the achievement of educational goals is to produce graduates who have competency and good quality from all sides, both scientific and personality. If the quality of work of teachers is not good, as a result the learning process implemented by teachers is also not good and also has an impact on students in learning so that the competence and quality of students does not develop optimally. Thus, educational goals are not achieved.

Based on the results of a preliminary survey in August 2016 of the implementation of the task of 30 State Junior High School teachers in Jambi City, information was obtained that the quality of teacher work was still low, still not as expected. This can be seen from the responses of the respondents through preliminary instruments (appendix 1 and appendix 2) regarding the dimensions / indicators of the quality of teacher work, the following trends:

1) There were $61.7 \%$ of the teachers surveyed showed problematic indications in the dimension of Personal Development, especially in the indicators of professional development, namely in preparing plans for implementing learning, developing student personality, and in encouraging students to behave honestly.

2) There are $57.4 \%$ of the teachers surveyed showed a problematic indication in the Initiative and Acting dimensions in carrying out the work (Teaching and Learning Activities), especially in terms of developing a learning syllabus and taking the initiative in the implementation of supporting work, and objectively reporting student achievement reports.

3) There are $60 \%$ of the teachers surveyed showing problem indications in the dimension in the dimension of Social Life, especially in terms of getting high social status and in relationships with colleagues.

4) There are $76.7 \%$ of the teachers surveyed showed a problematic indication in the Evaluation in Work dimension, especially in terms of understanding students' progress in each of their character development.

The results of a preliminary survey about the quality of teacher work against some of the dimensions / indicators above, of course, are very unexpected, because the government focuses on teachers to be able to carry out their main tasks and functions in the learning process properly. To support the quality of teacher work, the government has issued a regulation on the Law on National Education System (UUSPN) No. 20 of 2003, Law on Teachers and Lecturers No. 14 of 2015, Government Regulation No. 19 of 2005 concerning National Education Standards, and Teacher 
Certification. All of these regulations are basically an attempt by the government to organize and improve the quality of teacher work.

Many factors are thought to affect the low quality of teacher work can be influenced by several factors including, among others: the principal's leadership style, interpersonal communication, Pedagogical Competence, job satisfaction, school climate, school principal supervision, professional attitude, availability of facilities and infrastructure, work commitment, pedagogical competence, work environment, Principal Supervision and work discipline. In this case, the study only analyzes three factors that affect the quality of teacher work, namely: supervision of the principal, work discipline and teacher pedagogical competence.

The quality of work of teachers is highly determined from the whole set of activities and activities at the organization / school, the quality of work is inseparable from the guidance provided by the principal. Guidance conducted by the school principal is supervised. Supervision of the principal is a process of guidance from the principal to the teachers in managing the learning process which includes planning, implementing and evaluating learning. The coaching process that is continually carried out by the school principal is believed to be able to encourage and influence teachers to always make improvements to the learning process and carry out the main tasks and functions optimally.

School organizations strive in various ways in achieving their goals, including the start of a teacher who must improve the quality of his work, a teacher who has an effective work ethic, good performance will contribute a lot in achieving educational goals. Organizations need the support of teacher work discipline. In order to create a work climate that is full of comfort, balance and harmony in the process of running the system in the school organization. Good work discipline will strongly support the smoothness, delivery of tasks and organizational messages, will create openness and support among its members.

The good quality of teacher's work is a reflection of the work system of all individual schools that are indispensable for achieving educational goals. For this reason, a teacher needs to take a role to the extent that it can facilitate the work of its personnel in a conducive manner by having good pedagogical competence in achieving educational goals. The quality of work will be good if it is supported by the supervision of good principals, good work discipline and good pedagogical competence, this condition will encourage attitudes that want to change for progress and the achievement of organizational goals, namely improving the quality of education.

Schools as an organization in which there are personal teachers, need to develop teacher pedagogical competencies. The pedagogical competence referred to is the ability that must be owned and mastered by a teacher owned by a teacher in order to carry out their main tasks and functions, such as mastering teaching materials, mastering teaching methods, being able to manage teaching and learning programs, being able to manage classes, being able to manage and utilize learning media, and able to evaluate learning.

Characteristics of the organizational environment over time continues to experience change, it requires a leadership model that can encourage the spirit of change in the members of the organization. Work discipline can be adopted to provide the driving force for change. Work 
Discipline as a leader who has the power to influence subordinates in certain ways. Subordinates feel trust, admiration, loyalty and respect for their superiors so that subordinates are motivated to do more than what is usually done and expected.

In the education unit organization, the work discipline of the school principal can encourage, direct, and motivate all school members to work together in realizing the vision, mission and goals of the school. Principals as leaders, have an obligation to create job satisfaction for teachers, because job satisfaction is a factor that is believed to be able to encourage and influence the work spirit of teachers so that they can work well and will directly affect a good and pleasant working atmosphere.

The conducive working environment of a school influences the attitudes and actions of the whole community, especially on the achievement of students' academic achievement. Student academic achievement is strongly influenced by the mental atmosphere or school work climate. Productive culture is a culture that can make an organization strong and organizational goals can be accommodated. The work environment which is part of the supervision of school principals is one of the factors that influence teacher performance. Teachers who feel a conducive working atmosphere at school, it is expected that teacher performance will increase, and if teacher performance increases, students will achieve satisfactory academic performance.

Supervision of a good Headmaster can develop the potential of human resources in the development of science and creativity, as well as looking for new ideas so that they can apply them in a process of providing education to create quality human beings. Interpersonal communication carried out between leaders and subordinates, in this case between the principal and teachers strived to increase good and effective cooperation to achieve success is also useful as one of the strong foundations in achieving maximum teacher performance.

The teacher in implementing the learning process, in addition to providing knowledge to students, is also expected to instill discipline. Discipline can be interpreted as a condition that makes or causes or gives impetus to someone to do and do all activities in accordance with established norms or rules. Discipline is a process of self-control, in which the formation of discipline requires a fairly long process full of responsibilities. A teacher must be able to provide an example of discipline to students, because the figure of a disciplined teacher will be a role model for students and at the same time as a standard teacher who has responsibilities.

Complete educational facilities and infrastructure will be in vain without the support of respect for teacher achievement and competence. Conversely the lack of facilities and infrastructure will actually be a whip of success if based on attitudes toward achievement and strong teacher competence to achieve success. Teacher pedagogical competence is still one of the basic problems of teachers in Indonesia. There are still teachers, especially in areas that do not pass the competency test and certification due to the low quality of these teachers. The results of the competency test over the past three years indicate the quality of teachers in Indonesia is very low. Many teachers do not understand the scientific substance that is owned or the right learning patterns to be applied to students. 
In essence many previous researchers have tested variables such as those to be tested in this study, but of course there are differences in the number and characteristics of the subjects or units of analysis studied. In this study the unit of analysis is the teacher status of the State Civil Apparatus (ASN) who served in the State Junior High School in Jambi City. Based on this phenomenon, then in this study the title "Relationship between School Principal Supervision, Teacher Work Discipline, Pedagogical Competence and Teacher Quality Work".

\section{Theory Study}

\subsection{The Nature of the Quality of Teacher's Work}

Mohammad Baitul Islam stated that the quality of work life is a concept of a balance between personal life and professional life of individuals, which is reflected in satisfaction with the situation / social environment and the limited physical facilities available. The quality of work life can be seen from: a. An opportunity to implement one's talents and abilities, b. Independent initiatives and self-direction (freedom of initiative and determination of action), c. Individual activities to be valuable by individual involvement, $\mathrm{d}$. The role of the individual in the achievement of some overall goal is understandable (Recognition of individual achievement in achieving organizational goals) and e. Sense of taking pride in what one is doing and in doing it well (Pride in performance performed)

According to Freyedon Ahmadi, Adel Salavati, and Ebrahim Rajabzadeh, the quality of work life is the feelings and perceptions of individuals about work, work colleagues and the organization where they work. Some factors for the quality of work life are as follows: a. Individual Growth and Development (the opportunity to advance and develop themselves), b. Participation in formulating the objectives (Participation in setting work goals), c. Pay and benefits received (salary and welfare received), d. Social Integration in doing the jobs, and e. Supervision from the superior. The quality of teacher work is the individual's feelings and perceptions about the balance of personal and professional life in relation to work, coworkers and the organization where he works.

\subsection{The Principal Supervision Principle}

Leslie W. Rue and Lloyd L. Byars stated that Supervision is the first level of management within an organization that focuses on encouraging members of the work unit to contribute well (positive) in order to achieve the goals and objectives desired by the organization. Supervision is the first level of management in the organization that focuses on encouraging or encouraging members of the work unit to contribute well (positively) in order to achieve the goals and objectives of the results desired by the organization. There are several factors that must be considered in carrying out supervision, namely: a. Good planning (planing); b. Good communication with subordinates (Communicate well with people); c. Provide Motivation (Motivate people); and D. Provide training (train people).

According to Carl D. Glickman, Stephen P. Gordon and Jovita M. Ross-Gordon Supervision is viewed most often as an instrument for controlling teachers. Supervision is the glue of a successful school. Supervision is a function that draws together the discrete elements of the school into all the school's actions for the efficacy of learning. Supervision is seen most often as an effort to 
supervise teachers. Supervision is the glue of a successful school. Supervision is an attempt to jointly discrete elements in the school into all school actions for the advancement of learning.

Supervision of school principals is a form of service performed by school principals on teacher activities with the intention of monitoring, evaluating, directing and guiding so that the process of implementing teacher assignments can run well in accordance with planned goals.

\subsection{The Nature of Work Discipline}

J.M. Ivancevich explained that discipline (Discipline) is an effort to prevent the emergence of negative behavior, and apply penalties for behavior that violates (undesirable). The factors that affect discipline, namely: a. Rules for being disciplined in working and behaving; $b$. Communication of disciplinary rules to employees; c. An assessment of employee behavior based on disciplinary rules; and D. Systems and procedures for applying reprimands and sanctions for violations of discipline.

Gary Dessler revealed that discipline is efforts in the form of rules aimed at ensuring orderliness and protection of employee safety. Discipline can be improved through: a. Inspections of employees at work; b. Provisions that foster employee awareness to work in an orderly manner and give priority to safety; and c. Stipulation of sanctions for violations of employee behavior.

Henry Simamora believes that work discipline is a procedure that corrects or punishes subordinates for violating rules or procedures. Discipline is a form of employee self-control and regular implementation and shows the level of sincerity of the work team in an organization. The application of work discipline can be seen from: a. procedures and responsibilities, b. supervisory responsibilities, c. communication regulations, d. responsibility for the presentation of evidence, e. consistency, f. consideration of the situation, and g. regulations, and penalties.

Discipline is efforts in the form of formal rules (provisions) set by the organization and aims to prevent the emergence of violating employee behavior, as well as to maintain work order, and safety protection at work.

\subsection{The Nature of Pedagogical Competence}

According to Buchari Alma, pedagogical competence, namely the ability to manage student learning, includes the concept of teaching readiness that is demonstrated mastery of knowledge and teaching skills, understanding of students, understanding of educational insight, syllabus development, designing or implementing learning that educates and dialogues, evaluates learning outcomes, develop students to actualize the various potentials they have. Pedagogic competencies of a teacher can be characterized by: a. Teaching planning; b. Teaching skills; c. Understanding of student characteristics; d. Syllabus development; and e. evaluation.

Pedagogic competence is the ability to manage learning. Pedagogic competencies that must be possessed by teachers include: a. Know the characteristics of students, b. mastering the theory of learning and principles of learning that educate, c. curriculum development, d. learning activities 
that educate, e. potential development of students, f. communication with students, g. assessment and evaluation.

Trianto stated that pedagogical competence, namely: the ability to understand students in depth. The teacher's pedagogical competencies are: a. Organization of learning that educates, $b$. understanding of students, c. the ability to design learning, d. implementing learning, e. assessing the process of learning outcomes, and f. make improvements on an ongoing basis. Teacher pedagogic competence is a skill or ability that must be mastered by a teacher in seeing the characteristics of students from various aspects of life, be it moral, emotional, or intellectual.

\section{Research Methodology}

This research uses mixed methods research method with sequential explanatory design. This study combines or combines two studies, namely: qualitative research and quantitative research. According to Sugiyono stated that the research into a combination of sequential explanatory design is a combination research method that combines quantitative and qualitative research methods sequentially, where in the first stage the research was conducted using quantitative methods and in the second stage was carried out with qualitative methods. Quantitative methods are used to get measurable quantitative data, and qualitative methods are used to prove, deepen, expand, give meaning to quantitative data that have been obtained at an early stage.

The constellation of the problem under investigation is shown in Figure 5, as follows:

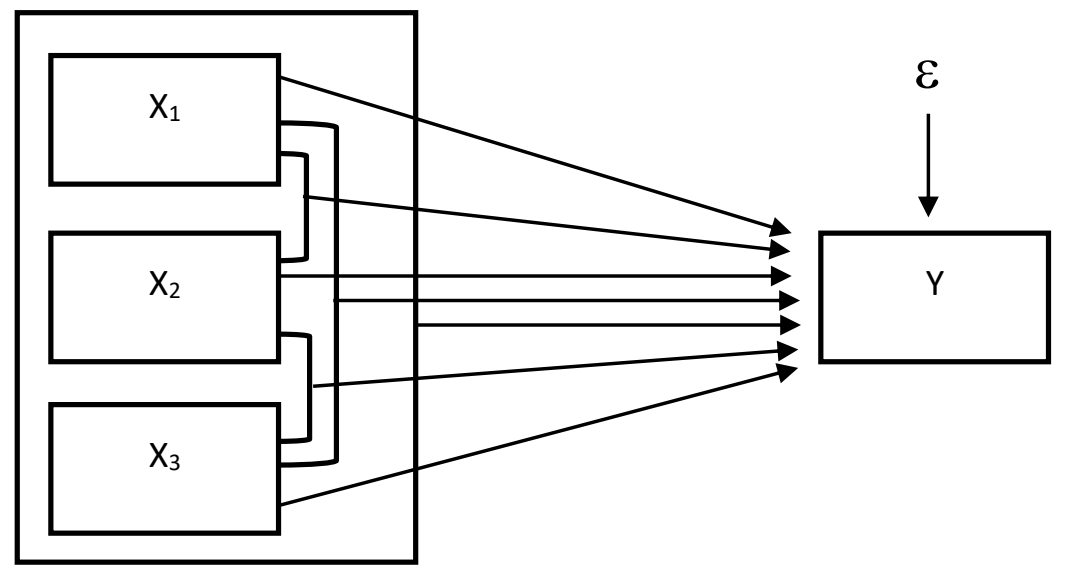

Image Constellation of Research Problems

Keterangan:

$\mathrm{X}_{1} \quad$ : Principal Supervision Principle

$\mathrm{X}_{2} \quad$ : Work Discipline

$\mathrm{X}_{3} \quad$ : Pedagogical Competence

Y : The Quality of Teacher's Work.

$\varepsilon$ (epsilon) : Other related variables 


\section{Research and Discussion Results}

There is a very significant positive relationship between the supervision of the principal and the quality of teacher work with the correlation coefficient $r=0,4612(\alpha=0.01)$, the coefficient of determination $\mathrm{r} 2=21.27 \%$ and the regression equation $\hat{\mathrm{Y}}=83.539+0.450 \mathrm{X} 1$, it means that the higher the supervision of the school principal will also increase the quality of teacher work; There is a very significant positive relationship between work discipline with the quality of teacher work with the correlation coefficient $r=0.4834(\alpha=0.01)$, the coefficient of determination $r 2=23.37 \%$ and the regression equation $\hat{Y}=91.901+0.427 \mathrm{X} 2$, meaning the higher the work discipline, the better the quality of teacher work will be.

There is a very significant positive relationship between pedagogical competence and the quality of teacher work with the correlation coefficient $r=0.5082(\alpha=0.01)$, the coefficient of determination $\mathrm{r} 2=25.83 \%$ and the regression equation $\hat{\mathrm{Y}}=81.215+2.011 \mathrm{X} 3$, meaning the higher the pedagogical competence, the better the quality of teacher work will be. There is a very significant positive relationship between supervision of the principal and work discipline together with the quality of teacher work with the correlation coefficient $r=0.5815(\alpha=0.01)$, the coefficient of determination $\mathrm{r} 2=33.81 \%$ regression equation $\hat{\mathrm{Y}}=43.63+0.403 \mathrm{X} 1+0.388 \mathrm{X} 2$, meaning that the higher the supervision of the school principal and work discipline together, the higher the quality of teacher work.

There is a very significant positive relationship between the supervision of the principal and pedagogical competence together with the quality of teacher work with the correlation coefficient $\mathrm{r}=0.6188(\alpha=0.01)$, the coefficient of determination $\mathrm{r} 2=38.29 \%$ regression equation equation $=32.95+0.413 \mathrm{X} 1+1.953 \mathrm{X} 3$, this shows that the higher the supervision of school principals and pedagogical competencies together, the better the quality of teacher work. There is a very significant positive relationship between work discipline and pedagogical competence together with the quality of teacher work with the correlation coefficient $r=0.5762(\alpha=0.01)$, the coefficient of determination $\mathrm{r} 2=33.20 \%$ regression equation $\hat{\mathrm{Y}}=48.18+0.333 \mathrm{X} 2+1.646 \mathrm{X} 3$, this shows that the higher the work discipline and pedagogical competence together, the better the quality of teacher work will be.

There is a very significant positive relationship between the supervision of the principal, work discipline, and pedagogical competence together with the quality of teacher work with the correlation coefficient $r=0.7171(\alpha=0.01)$, the coefficient of determination $r 2=51.43 \%$ regression equation $\hat{\mathrm{Y}}=7.373+0.286 \mathrm{X} 1+0.388 \mathrm{X} 2+1.643 \mathrm{X} 3$, this shows that he higher the supervision of school principals, work disciplines, and pedagogical competencies together, the higher the quality of teacher work will also increase.

The results of this study also indicate that the pedagogical competency variable has the highest value of connectedness compared to other independent variables, namely: supervision of school principals and work discipline. Based on the findings obtained in this study, it can also be seen that the improvement in the quality of teacher work is the result of the supervision of principals, work discipline and pedagogical competencies together and it is estimated that other variables that have a relationship with improving the quality of teacher work, namely: leadership, organizational culture, work motivation, interpersonal communication, work commitment, emotional 
intelligence, job satisfaction, work environment, professional attitude, availability of facilities and infrastructure, and school climate.

\section{Conclusion}

Based on the results of quantitative data analysis and discussion of research results, it is known that the value of the relationship between the independent variable and the dependent variable can be seen from the coefficient of determination. The coefficient of determination of the principal's supervision variable is ry $1^{2}=0.2127(21.27 \%)$, the work discipline variable is ry $2^{2}=0.2337$ $(23.37 \%)$, and the pedagogical competency variable is ry $1^{2}=0.2583(25,83 \%)$.

Referring to the data above, it means that $25.83 \%$ of the quality of teacher work is the result of the work of pedagogical competencies to contribute to improving the quality of teacher work. Thus, pedagogical competence is a priority in improving work quality by providing reinforcement of indicators of pedagogical competency variables and work quality intensively so that the implementation of training becomes effective and efficient in accordance with the needs of teachers in carrying out basic tasks and functions so as to create optimal performance.

Therefore, all aspects related pedagogical competency variables and work quality become the basis for developing a follow-up program (Action Plan). Strengthening pedagogical competency indicator indicators sequentially from the largest to the smallest as follows: a) assessment of learning achievement $0.86, \mathrm{~b}$ ) mastery of pedagogical competence 0.85 , c) student management mastery 0.80 , and d) management mastery of grade 0,80 Thus, the sequence of the process of improving the quality of teacher work through strengthening indicators of pedagogical competency variables starts from the largest value to the smallest. The action plan program in this study was arranged based on all aspects of pedagogical competency indicator variables and work quality. This is intended to be an alternative material to be considered and a priority for the program that will be implemented in stages in an effort to improve the quality of teacher work.

\section{References}

[1] Akhyak, Mohamad Idrus, dan Yunus Abu Bakar, Implementation of Teachers Pedagogy Competence to Optimizing Learners Development in Public Primary School in Indonesia, International Journal of Education and Research Vol. 1 No. 9 September 2013

[2] Ali Mohammad Mosadeghrad, Quality of Working Life: An Antecedent to Employee Turnover Intention. International Journal of Health Policy and Management. Vol. 1(x), 1-10. Iran: Tehran University of Medical Sciences, 2013.

[3] Anonim, Pedoman pelaksanaan kinerja guru (PK Guru). Buku 2. Jakarta: kementerian Pendidikan dan Kebudayaan Dirjen PMPTK, 2012.

[4] Anwar Hossain dan Nahid Aktar, "Influence of Perceived Organizational Support, Supervisory Support, and Working Environment on Employee Service Quality: An Empirical Study on NonGovt. Employees in Bangladesh". Journal Knowledge \& Character, Presidency University, Volume 1 January 2012 Number 1, ISSN: 22247610, http://presidency.edu.bd/uploads/pu-journalpart-A.pdf

[5] Anwar Prabu Mangkunegara dan Tinton Rumbungan Octorend, Effect of Work Discipline, Work Motivation and Job Satisfaction on Employee Organizational Commitment in the Company (Case 
Study in PT. Dada Indonesia), Universal Journal of Management 3(8): 318-328, 2015 DOI: 10.13189/ujm.2015.030803 http://www.hrpub.org

[6] B. Siswanto Sastrohadiwiryo, Manajemen Tenaga Kerja Indonesia, edisi 2 Jakarta:Bumi Aksara, 2003.

[7] Bipoupout Jean Calvin and Nguefo Evelyn Chumba, Teacher's pedagogic competence and pupils' academic performance in English in Francophone schools, Educational Research (ISSN: 21415161)Vol. 2(4) pp. 1094-1105 April 2011 Available online@ http://www.interesjournals.org/ER Copyright (C) 2011 International Research Journals

[8] Buchari Alma, Guru profesional: Menguasai Metode dan Terampil Mengajar, (Bandung: Alfabeta, 2010)

[9] Cascio, Wayne F., Managing Human Resources. Colorado: Mc Graw - Hill, 2006.

[10] Chandranshu Sinha, Factors Affectiung Quality Of Work Life: Empirical Evidence From Indian Organizations, Australian Journal of Business and Management Research Vol.1 No.11 [31-40] | February-2012

[11] Dessler, Gary., Human Resource Management. Upper Saddle River, NJ: Prentice-Hall, 2008,

[12] Devappa Renuka Swamy, Nanjundeswaraswamy dan Srinivas Rashmi, Quality of Work Life: Scale Development and Validation. International Journal of Caring Sciences May-August 2015 Volume 8 Issue 2 Page 28

[13] E. Mulyasa, Manajemen Berbasis Sekolah, (Bandung: Remaja Rosdakarya, 2002)

[14] E. Mulyasa. Standar Kompetensi dan Sertifikasi Guru. (Bandung: Remaja Rosdakarya, 2007),

[15] E.D. Nakpodia, The Dependent Outcome of Teachers Performance in Secondary Schools in Delta State: An Empirical Assessment of Principal's Supervision Capacity, African Journal of Education and Technology, Volume 1 Number 1, April 2011; pp. 15-24

[16] Engkoswara dan Aan Komariah, Administrasi Pendidikan. (Bandung: Alfabeta, 2011).

[17] Flippo, Edwin B, Manajemen Personalia, (Jakarta: Erlangga, 2001)

[18] Freyedon Ahmadi, Adel Salavati, and Ebrahim Rajabzadeh. 2012. Survey Relationship between Quality of Work Life and Organizational Commitment in Public Organization in Kurdistan Province. Interdisciplinary Journal of Contemporary Research in Business, Vol. 4, No.1, (May).

[19] Gayathiri, R., and Ramakhrisnan, R. 2013. Quality of Work Life - Linkage with Job Satisfaction and Job Performance. International Business and Management Invention, Volume 2, Issue 1, pp. 01-08.

[20] Glickman,Carl D., Stephen P. Gordon and Jovita M. Ross-Gordon, Supervision and intructional Leadership, 2009

[21] Goodwin, A. Lin,. \& Clare Kosnik (2013) Quality teacher educators = quality teachers? Conceptualizing essential domains of knowledge for those who teach teachers, Teacher Development: An international journal of teachers' professional development, 17:3, 334-346, DOI: 10.1080/13664530.2013.813766, http://dx.doi.org/10.1080/13664530.2013.813766

[22] Greenberg, Jerald,. and Robert A. Baron. Behavior in Organizations. Upper Saddle River, NJ: Prentice-Hall, 2008,

[23] Hanushek 2002 Teacher Quality.pdf, accessed May 17, 2016, http://hanushek.stanford.edu/sites/default/files/publications/Hanushek\%202002\%20Teacher\%20 Quality.pdf.

[24] Henry Simamora, Manajemen Sumber Daya Manusia. Edisi Ketiga. Yogyakarta: Aditya Media, 2006.

[25] Hermin Arista, Eddy Sutadji dan Hakkun Elmunsyah, "Contribution of Competence and Teaching Experience to the Teacher Work Motivation and Teacher Work Quality Also Its Effect to the Student Learning Outcome". IOSR Journal of Research \& Method in Education (IOSR-JRME) eISSN: 2320-7388,p-ISSN: 2320-737X Volume 6, Issue 1 Ver.III (Jan. - Feb. 2016), PP 07-13 www.iosrjournals.org 
[26] Itang, Work Discipline and Work Competence with Quality of Service in the Office of Religious Affairs (KUA) District of Mount Kencana Lebak Regency of Banten. Journal of Management and Sustainability; Vol. 5, No. 3; 2015, ISSN 1925-4725 E-ISSN 1925-4733, Published by Canadian Center of Science and Education, doi:10.5539/jms.v5n3p132

URL: http://dx.doi.org/10.5539/jms.v5n3p132

[27] Ivancevich, J.M., Human Resource Management. New York: McGraw-Hill, 2010,

[28] Jejen Musfah, Peningkatan Kompetensi Guru:Melalui Pelatihan dan Sumber Belajar Teori dan Praktik, Cet. Ke-1, Jakarta: Kencana, 2011

[29] Karnadi, Peraturan Pemerintah RI nomor 74 tahun 2008 tentang Guru, Jakarta: BP. Cipta Jaya, 2009.

[30] Kunandar, Guru Profesional: Implementasi Kurikulum Tingkat Satuan Pendidikan dan Sukses dalam Sertifikasi. Jakarta: Raja Grafindo Persada, 2007.

[31] Lijan Poltak Sinambela, Manajemen Sumber Daya Manusia; Membangun Tim Kerja yang Solid untuk Meningkatkan Kinerja, Jakarta: Bumi Aksara, 2016.

[32] M. Ngalim Purwanto, Administrasi dan Supervisi Pendidikan, Cet. 19 (Bandung: Remaja Rosdakarya, 2009)

[33] Madhavaram, S., Laverie, D.A. (2010). Developing Pedagogical Competence: Issues and Implications for Marketing Education. Journal of Marketing Education, vol. XX, no X, pp. 2-10

[34] Malayu S.P. Hasibuan (Manajemen Sumber Daya Manusia. Jakarta: Bumi Aksara, 2010. pp. 192198

[35] Martinis Yamin, Sertifikasi Profesi Keguruan di Indonesia, Cet. Ke-2, Jakarta: Putra Grafika, 2007, p. 2

[36] Maura and Sellars, "Teachers and Change: The Role of Reflective Practice," Procedia - Social and Behavioral Sciences, 3rd. International Conference on New Horizons in Education - INTE 2012, 55 (October 5, 2012): 461-69, doi:10.1016/j.sbspro.2012.09.525.

[37] Mohammad Baitul Islam, Factors Affecting Quality of Work Life: An Analysis on Employees of Private Limited Companies in Bangladesh. Global Journal of Management and Business Research Volume 12 Issue 18 Version 1.0 Year 2012 Type: Double Blind Peer Reviewed International Research Journal Publisher: Global Journals Inc. (USA) Online ISSN: 2249-4588 \& Print ISSN: 0975-5853, GJMBR-A Classification: FOR Code: 150305, 150311 JEL Code: J28, O15.

[38] Mohammad Baitul Islam. 2012. Factors Affecting Quality of Work Life: An Analysis on Employees of Private Limited Companies in Bangladesh. Global Journal of Management and Business Research, Vole 12, Issue 18, Version 1.0.

[39] Muhammad Idris, The Impact of Supervision, Motivation and Work Ethic on Teachers' Professional Competence: A Case Study of Private Islamic High School Teachers. Macrothink Institute ${ }^{T M}$ International Journal of Human Resource Studies ISSN 2162-3058 2016, Vol. 6, No. 1, doi:10.5296/ijhrs.v6i1.9073 URL:http://dx.doi.org/10.5296/ijhrs.v6i1.9073, pp. 147-158

[40] Myint Swe Khine, A. Lourdusamy, Quek Choon Lang, Angela F.L. Wong. Classroom management. Singapore: Prentice hall, 2005, p. 194

[41] Preethi vijaimadhavan dan D. Venkatarama Raju, An Empirical Study on relationship among Quality of work life and its factors. IOSR Journal of Business and Management (IOSR-JBM) $e$ ISSN: 2278-487X, p-ISSN: 2319-7668. Volume 12, Issue 3 (Jul. - Aug. 2013), PP 20-28 www.iosrjournals.org

[42] Riduwan. Skala Pengukuran Variabel-variabel Penelitian. (Bandung: Alfabeta, 2007), Hal. 65

[43] Robbins, Stephen. P., Organizational Behavior. Upper Saddle River, NJ: Prentice-Hall, 2003

[44] Rue, Leslie W.,and lloyd L. Byars, Supervision Key Link to Productivity. 2008,

[45] Sedarmayanti, Sumber Daya Manusia dan Produktivitas Kerja, Bandung: Mandar Maju, 2001.

[46] Selahattin Kanten dan Omer Sadullah, An Empirical Research on Relationship Quality of Work Life and Work Engagement, Procedia - Social and Behavioral Sciences 62 (2012) 360 - 366, 1877 0428 () 2012 Published by Elsevier Ltd. 
[47] Sudjana, Metoda Statistik. (Jakarta, Tarsito, 2005)

[48] Sugiyono, Metode Penelitian Administrasi, (Bandung: Alfabeta, 2004)

[49] Sugiyono, Metode Penelitian Kombinasi (Mixed Methods), (Bandung: Alfabeta, 2011),

[50] Sugiyono. Cara Mudah Menyusun, Skirpsi, Tesis dan Disertasi, (Bandung: Alfabeta, 2013),

[51] Sugiyono. Metode Penelitian Kombinasi (Mixed Methods). (Bandung: Alfabeta, 2011),

[52] Suharsimi Arikunto, Dasar-Dasar Supervisi, (Jakarta: PT Rineka Cipta, 2010),

[53] Sulistiyani, True, Amber, \& Rosidah. Human Resource Management. London: Graha Science, 2010

[54] Suryosubroto, Proses Belajar Mengajar di Sekolah, (Jakarta: Rineka Cipta, 2002)

[55] Suyadi Prawirosentono, Filosofi Baru tentang Manajemen Mutu terpadu abad 21. Jakarta: Bumi Aksara, 2007.

[56] Syaiful Sagala, Administrasi Pendidikan Kontemporer (Bandung: Alfabeta, 2006),

[57] Syaiful Sagala, Kemampuan Profesional Guru dan Tenaga Kependidikan. Bandung: Alfabeta, 2011.

[58] Trianto, Tinjauan Yuridis Hak serta Kewajiban Pendidik Menurut UU Guru dan Dosen. Jakarta: Prestasi Pustaka, 2006. Veithzal Rivai, Manajemen Sumber Daya Manusia untuk Perusahaan. Jakarta: Murai Kencana, 2004.

[59] Victor Obule Ebuara and Maurice Ayodele Coker, Influence of Staff Discipline and Attitude to Work On Job Satisfaction Lecturers in Tertiary Institutions in Cross River State, Public Policy and Administration Research ISSN 2224-5731(Paper) ISSN 2225-0972(Online) Vol.2, No.3, 2012, www.iiste.org

[60] Yunusa Dangara Usman, The Impact of Instructional Supervision on Academic Performance of Secondary School Students in Nasarawa State, Nigeria, Journal of Education and Practice www.iiste.org ISSN 2222-1735 (Paper) ISSN 2222-288X (Online) Vol.6, No.10, 2015 pp. 160-167

[61] Zepeda, Sally J., Instructional Supervision Applying Tools and Concepts, Eye on Education, (Library of Conggres Cataloging-in-Publication Data, 2003) 